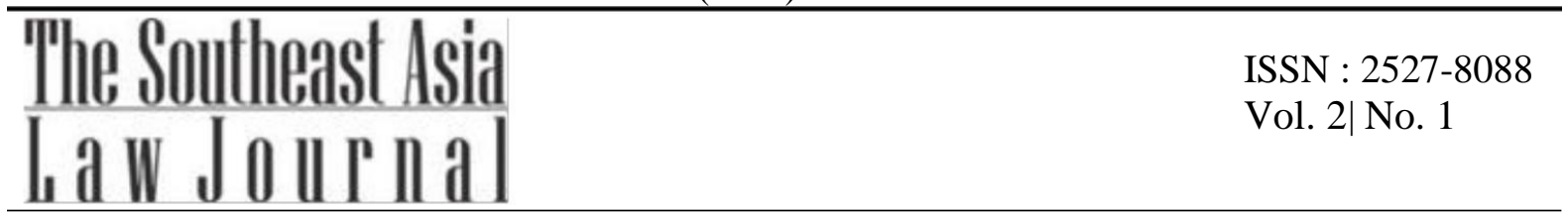

\title{
The Legal Policy of Corporation Legal Standing as Rechtpersoon at Indonesian Criminal Justice System
}

\author{
Maryano* Yuhelson* \\ **Universitas Jayabaya

\begin{tabular}{l}
\hline Article Info \\
\hline Keywords: \\
Corporate crime of law politics, \\
legal standing, subject crime of law.
\end{tabular} \\ Abstract \\ can lead to potential violations law or corporate crime. \\ The criminal action corporations can arised because the \\ impact of corporate activities arising from business \\ contracts, product quality problems, failure of \\ information technology systems and negligence of the \\ administrative requirements for business licensing \\ compliance. In other words, the legal entity of crime was \\ often referred as corporate crime as violations \\ committed by businesses to profit more quickly and \\ Corresponding Author: \\ maryono@gmail.com \\ The Southeast Asia Law Journal \\ Volume 2 Nomor 1 \\ Juli-Desember 2016 \\ ISSN 2087-9415 \\ pp. 1 - 15 \\ (C2016 SALJ. All rights reserved. \\ maintains the company's reputation. The study \\ concluded, first, the political dimension of the criminal \\ law on corporation has general nature, that political \\ criminal law founded in Criminal Code Bill which are \\ oriented to the development of law by placing the \\ corporation as a criminal, and need a codification law \\ of Corporation. Second, The political criminal law also \\ has special nature, which is found in 16 laws examined, \\ in the contexts of criminal responsibility concepts and \\ application of pattern of criminalas well as models of \\ criminal sanctions can be imposed on perpetrators of \\ criminal acts of the corporation.
}

\section{Introduction}

The development of life affects the keajegan legal structure as one of the social subsystem. There has been a shift in position between the legal subject of a legal entity (corporation), which moves toward a role originally held by a legal subject person.
Corporations in all its forms make a concrete contribution to the economic growth of the state in order to improve the welfare of the people (Undang Undang No 40 tengang perseroan terbatas, 2007), in accordance with the 1945, Constitution of the Republic of Indonesia (Constitution of the Republic of Indonesia) as the 
Constitution or the supreme law (Attamimi, 2005), has guaranteed legal entity other than the person as the subject of development as well as the object of purpose the establishment of NKRI. The Fourth Paragraph Preambule of the 1945 Constitution implicitly asserts:

Then to form a State Government of Indonesia that protects the entire nation of Indonesia and the entire blood of Indonesia and to promote the general welfare, educate the life of the nation, and participate in implementing the world order based on freedom, eternal peace and social justice, then the Indonesian National Independence it is in an Indonesian State Constitution, which is formed in the composition of the Republic of Indonesia with the sovereignty of the people (NKRI, 1945)

In the traffic law, the state regulates, protects, and participates in the life of the legal subject of the person as well as the legal subject of the legal entity. Corporation has been recognized, accepted, and lives in the practice of nation and society. Corporations are one component in people's lives that have an important role in the modern era relating to professional economic actors appearing in the category of legal subjects. (BUMN.go.id, 2016) In other words, corporations intersect with the performance and responsibilities of professional groups, such as law firms, accounting firms, and corporate legal entities, with management symbols.

The existence of corporations can be seen from two sides, namely the side of the establishment documents in the form of deed of incorporation containing the corporate and physical corporation corporation's corporate articles. Corporations have the same rights and duties as natural persons, so they can carry out legal and economic activities just like natural people. It can be said that corporations are essentially functional.

In construction and criminal law, initially the responsibility for corporate criminal action, especially in the formulation of sanctions, becomes the burden and responsibility of the individual committee. In general, the provisions of criminal law materil more emphasize the legal sanction arrangements on the members of the board or commissioners, among others implied in the formulation:

In cases where the violation is criminalized against the board, members of the governing body or commissioners, the board, member of the governing body or commissioner who does not interfere with the offense is not punished. (Adi setyadi dan Rena Yulia, 2010)

The fabric of criminal law construction seen in the context of civil law is evident in the 
case that corporations can be categorized as responsible parties and can therefore be placed as subjects in criminal offenses. The Indonesian Criminal Code (KUHP) stipulates that a commissioner or commissioner of a limited liability company, an Indonesian carrier airline or a cooperative association declared in a state of bankruptcy or ordered to be resolved by a court, is punishable by imprisonment for a maximum of 1 (one) (four) months. (KUHP

398) In other formulations it is found that a commissioner or commissioner of a limited liability company, an Indonesian carrier airline or a cooperative association declared in a state of bankruptcy or whose settlement is ordered by a court, shall be punishable by imprisonment of no more than 7 (seven) years. (KUHP 399)

Thus, the accountability of its origin in relation to civil law, but in its development, the extension of the responsible corporate crime as an independent legal subject may be subject to the burden of criminal liability.

Handling corporate cases is not as easy as identifying them as corporations have complex organizational structures, and are white collar crimes that are generally wellorganized, done by officials, professionals or corporations themselves, making it difficult to prove it. The corporate crime stems from the attractiveness between the professional and business aspects in the activity of giving priority to the business aspect. . (Quinney)

There are several modes performed and tagged corporate activity that is indicated to violate criminal provisions. First, the delivery or misrepresentation of the information in the financial statements which can be generally categorized as a violation of the criminal law related to the corporation. (Arifin, 2005)

Second, separating shareholder relationships with company management which, according to the analysis of management experts indicates that the fall of large companies. This coexist with weakness in applying the principles of Good Corporate Governance (GCG).

The disadvantage of applying GCG principles causes distrust of the existence of corporations as legal subjects and dichotomous questions of legal standing between corporations as entities with independent ones, or must be related to the board, when involved with a crime.

In the economic field there is the term fraud (fraud) that describes the situation more complex and diilematis, (asic.gov.au, 2016) when associated with the flow of funds (Theodorus, 2007). Complexity as it relates to the activities of the company indicated as part or purpose of a crime not yet regulated in a detailed legal system 
In the economic field there is the term fraud (fraud) that describes the situation more complex and dilematic, , (Naskah akademik ruu hukum acara pidana, 2008) when associated with the flow of funds. (Undang Undang no 3, 2011) Complexity as it relates to the activities of the company indicated as part or purpose of a crime not yet regulated in a detailed legal system.

Corporate fraud occurs because there are weaknesses in the application of corporate governance principles. (Undang undang no 6 tahun 2011) Fraud according to Black Law Dictionary is: (Black law Dictionary)

A knowing misrepresentation of the truth or concealment of a material fact to induce another to act to his or her detriment, is usual a tort, but in some cases (csp, when the conduct is willful) it may be a crime.

A misrepresentation made recklessly without belief in its truth to induce another person to act, A tort arising from knowing misrepresentation, concealment of material fact, or reckless misrepresentation made to induce another to act to his or detriment.

In this context, there is a problem of corporate criminal law. The problems that arise are the limits of corporate error and accountability related to a criminal act, especially in the field of economic crime. (Priyatno, 2010) It is necessary to conduct a proof process in accordance with the provisions of the law, because the evidence is one important factor in the judicial process, which can determine the position of the defendant whether it has met the elements of a criminal act. (Bakhri, 2009)

Law enforcement should also be humanized, in accordance with the principles of the rule of law. The process of disclosure of the condition of a corporation from internal or external, especially the company's financial condition can not be done carelessly. (Yeager, 1980) Determination of suspect status is required by the corporation as a legal entity to disclose information disclosure of bank accounts of parties involved in a crime. (Reksodiputro, 1993) On the other hand, putting a corporation as a suspect raises a high degree of difficulty. (Wiyono)

The corporation is in fact only a derivative (alter ego) of its shareholders, so sometimes the company is only used as a venture of shareholders in limiting the risk of loss arising from its involvement in the company for personal gain or for any other reason. (Definition of alter ego, 2016)

Theory of the State of Law or State by Law is a popular theory and is very general as the main theory in the study of law and state. This theory has grown since the days of the ancient Greeks to modern times today. (asshidiqie, 2008) Pure legal theory or positive law theory comes from the legal 
thought of the legal positivism madhhab which depicts the legalistic dimension of legalistic law. Theoretically and conceptually, on a simple level to understand "criminal offenses" should be seen in the Criminal Code (Criminal Code). However, the term or definition of a criminal offense is formally defined or its definition can not be found in the Criminal Code itself as a legal document or law that became the main reference for the term of a crime. To gain clarity on the definition, understanding, or description of the term criminal offense, it is more likely to refer to the substance of legal jurisprudence as developed by experts or experts in the field of Law Science.

\section{Research Method}

The dissertation research is classified into legal normative-dogmatic research (legal reseach), (Soekanto, 1986) because it is basically more emphasis on secondary data of library data to study and study the principles of positive law, comparative law, and elements or factors, related factors. In addition, relating to the object of research is also required primary data obtained directly from the field, meaning that in research there are elements of sociological-empirical legal research (socio legal research). Therefore, the method used is the Normative Juridical Method supported by the Empirical Jurisdiction.
The method of approach in normative research is usually used statutory approach (approach statute) and conceptual approach (conceptual approach) which is an integral part of normative analytical-juridical descriptive approach. The main source of normative research is the library as the usual place of secondary data resides and is found. The data is in the form of legal materials, both primary legal materials, secondary legal materials, as well as tertiary legal materials. Primary Legal Material is a legal material consisting of legal rules sorted by hierarchy of legislation starting from the Preamble and Body of the 1945 Constitution, TAP MPR RI. Legal material obtained from textbooks, legal journals, scholars' opinions, and symposia by experts

related to the discussion about Establishment of Legislation. Tertiary Law Material is a legal material that gives meaning or meaningful explanation of primary and secondary legal material such as legal dictionary, encyclopedia and others. The method of analysis used qualitative normative methods, namely research by describing the condition and facts about the object of research. The facts of this Law are analyzed by various laws, theories and doctrines or expert opinions aimed at finding answers to the issues to be discussed further. The approach is more abstract-theoretical, meaning that all data is compiled and then analyzed based on the categorization of 
problems or findings using a contextual mindset. The collection of secondary data in the library is done by sorting the existing legal lithography and grouping it according to the subject of the study. Because in approach that supported by normative juridical, can be done by field study to obtain primary data through interview.

\section{Result and Discussion}

Political Dimension of Criminal Law in Legal Standing of Corporation as Subject of Criminal Law

The criminal law of the corporation as a subject of criminal law is an integral part of the politics of national law. National legal politics is the act of choice of the various alternative choices of state policy makers in the field of law as a future law enforcement effort (ius constituendum). National legal politics in practice is reflected in a national legislation program that includes legal planning, legal drafting, legal executing and legal review.

The national legislation program is essentially a national planning program in the field of legislation. Lexically, the word program or program is defined as List of items, events, etc or plan of what is to be done. Meanwhile, the term legislation is defined in many meanings, namely: 1) The process of making or enacting a positive law in written form cording to the same type of formal procedure, by a branch of government constituted to perform this process; 2) The law so enacted; 3) The whole body of enacted laws.

In the context of national development planning, the overall ideological policy of the criminal law should include the renewal of the Material Criminal Law, the Formal Criminal Law and the criminal law. Efforts to renew its nature are included in the area of Penal Policy which is part of the law enforcement policy and social policy. Criminal Law reform should be conducted with a policy approach, so that the reform of the Penal Code should also be oriented towards a value approach.

Therefore, it can be concluded that the picture of the political dimension of law in the form of an effort to reform Criminal Law is part of the policy which includes: Policy to renew legal substance in order to effect law enforcement; Policies to combat or combat crime in the context of community protection; Policies to address social problems and humanitarian problems in order to achieve and support the national goals of social defenses and social welfare; and Efforts to review and re-assess the basic ideas, basic ideas, philosophical, socio-political and socio-cultural values that underlie criminal policies and enforcement policies of the Penal Code.

Criminal Law Politics means holding elections to achieve the best results of criminal legislation in the sense of meeting 
the requirements of justice and efficiency. The Politics of Criminal Law means the effort to realize the rules of criminal legislation in accordance with the circumstances and the situation at a time and for the future. Based on the scope of the Criminal Law Poi- sion and the Criminal Law policy line, it is determined how far the applicable criminal provisions need to be amended or updated, what can be done to prevent the occurrence of crimes, the

manner in which investigations, prosecutions, judiciary and enforcement of the Penal Code must be implemented .

Understanding the political of Criminal Law as stated above can be concluded that Criminal Politics is an attempt to determine which way of coming Criminal Law Politics will come to see and adjust the state of law enforcement at this time.

Politics of criminal law is basically based on the life of a changing society, in which there are values. There are several factors that cause change in the broad sense that is: There are human thoughts, through reason and mind given to God, will always evolve from time to time. This condition that causes man to always use his thinking in all aspects of life; The change, influenced by the demands or needs of humans.

Officially and formally, the law has not been published since it is still under discussion, but the political dimension of the criminal law is materially apparent in its material plan, among others: that, in the case of a criminal act of corruption committed by or on behalf of a corporation, and criminal detention may be committed against the corporation and / or its board and that the criminal act of corruption is committed by the corporation if the offense is committed by persons, whether based on employment or other relationship, acting within the corporate environment either alone or jointly. Politically legal, the laws and regulations in the type of Supreme Court regulations are intended as integrative guidelines of corporate criminal law enforcement system.

Enforcement of Corporate Criminal Law and Boundaries as Benchmark for Processing of Corporations as Subject of Criminal Law

The most common, the difficulty of criminal law enforcement for the subject of corporate law is the psychological aspect. Therefore, the limits of the benchmark are important to be examined from the point of view of the psychological nature of the corpotation. For example, in the case of giving testimony before the court or before the court, the corporation can not directly provide information without explanation from the management. This becomes complex if the corporation's management is also a party categorized as a suspect. The corporation is in fact only a derivative (alter ego) of its shareholders, so sometimes the company is 
only used as a venture of shareholders in limiting he risk of loss arising from its involvement in the company for personal gain or for any other reason.

According to criminal law theory, one characteristic of criminal law is the so-called mens rea, which serves as a general condition to be met by a crime. This is what distinguishes it from civil law. In mens rea must be covered by the nature of unlawful (wederrechtelijkheid), errors (Schuld), and the ability of responsible according to criminal law (toerekingingsvatbaar heid). According to the study and analysis of the researcher, it is this element or factor that causes the difficulty of law enforcers to this day, in enforcing the criminal law against the subject of corporate law, the element of mens rea is difficult in its size in corporations.

The criminal law perspective has developed into a broad meaning. In the sense of modern, criminal law must be seen and can be called the existence or the elements of criminal law, namely the existence of the subject of the perpetrator / maker, the element of error, elements can be accounted for his actions, the relationship or the psychic link between maker and deed (often called intentional or error in the narrow sense), there is no element of criminal abolition that can eliminate the accountability of an act to the offender or the maker.

Thus, referring to a description explaining the side of corporate criminal law enforcement as described above, it is clear that the discussion of boundary aspects as a benchmark to determine that a corporation as a subject of criminal law may be processed in criminal law enforcement is very important in view of the applicability of criminal law formal for corporations.

As mentioned briefly in the background section of research in Chapter I, the limits of corporate criminal law enforcement on the technical level of law enforcement relate to norms in procedural law, especially after a corporation is determined as a suspect.

Putting a corporation as a suspect creates a high level of difficulty. Technically there are also legal issues that are not easily understood, such as the difficulty of formulating the identity of the suspect in the Minutes of Examination (BAP) by the investigator and formulating the identity of the defendant in the indictment by the public prosecutor. It is stated so, because explicitlynormative Article 143 paragraph (2) letter a of the Criminal Procedure Code, determines the formal conditions containing the full name, place of birth, age or date of birth, sex, nationality, residence, religion and occupation of the suspect. By analogue the above formal terms refers to the identity of 
natural persons who are natural persons (naturlijk person) as subjects of criminal law.

For corporations there is no provision that can be referred to analogously. Such a situation will lead to the stagnant process of criminal law enforcement with corporate actors, since the weakness of formulating the identity in the indictment may be overturned by the judge.

Therefore, regarding the formal requirement of identity in the Indictment for corporation as a subject of criminal law is not fulfilled as stipulated in the Criminal Procedure Code. Whereas the mistake in formulating the identity of the defendant in the Indictment resulted in the indictment being revoked by the Judge. In this case the formal legal obstacles in criminal law enforcement for corporations that commit criminal offenses occur. Because if it is applied, the law of the indictment is not strong enough and the judge is authorized to cancel it.

Specifically, at the stage or level of proof, the disclosure process of the condition of a corporation from the internal and external side, especially the financial condition of the company can not be done carelessly. In this case the principle of openness can not be implemented the stage of corroboration law enforcement corporation. In relation thereto, the determination of the suspect's status is required by the corporation as a legal entity to disclose information disclosure of the bank account of the parties involved in the crime.

In other words, when a corporation has been established as a suspect of a criminal offense, there are difficulties. Among other things related to the financial condition of a corporation in the context of criminal proceedings can not be expressed openly, because it involves the internal side of the corporation. It requires a prerequisite, namely that against the corporation as a legal entity, the determination of the status of the suspect is required.

Judged from the point of view of law enforcement officers, there is a general lack of mastery of corporate aspects by members of the law enforcement apparatus, which should be understood as they are not equipped with special education on corporations. Consequently, in carrying out criminal law enforcement tasks against corporations many law enforcement officers only equip themselves with the right to discretion, without having the ability in the corporate field so often ignore the norms, principles, and all the provisions governing the corporation in legal traffic, to process a crime related to the existence of a corporation. That is, it actually contains weaknesses because the true discretion that exists in the realm of state administrative law tends to be easy to be guilty for when 
prosecuted by law administration enforcement officers, of the state tends to be easily guilty in the interests of law enforcement officials.

In the technical perspective of procedural law, it is likely that it is easier to process individual verification than the corporation due to several factors. First, the determination of the existence of a criminal act by the corporation (corporate crime) as part of a white collar crime can not be seen with ordinary eyewear such as against common crime. This is because: (1) corporate infringement is not as heavy and threatening as murder, robbery and others;

(2) occur in the office environment, not in the streets; (3) the victim's relationship with the perpetrator is indirect; and (4) often involve complex technological and financial problems, not easily detected by victims or law enforcement agencies. Secondly, there is difficulty in determining corporate mistakes (mens rea), because there is a complex relationship in organizational crime, which is interrelated between the executive director, the manager on the parent company side, and the divisions of the company (subsidiaries) on the other side.

In addition, proper matters should be considered as humanitarian, social, economic, and cultural aspects. It has become an adage that there is no unlawfulness which is in accordance with the law. Likewise, the presumption of innocence principle must be applied by law enforcement because it may be a violation of the law by the corporation that is an unconscious omission. On the contrary, it is also considered very unfair if the mistakes of one individual corporate management must be borne by another individual corporate administrator or innocent corporation. Individuals who are proven to be guilty of a corporation must be personally responsible.

Based on the theory of criminal law, one of the main principles in criminal law is the principle of legality, stating that there is no offense or punishable action (punishable) without first having a criminal-threatening rule (Nullum delictum, noella poena sine praevia lega poenali). Through the interpretation of a contrario, if a perpetrator's act is a material wederrechtelijkid but proven deeds formele not wederrechtelijkheid on the grounds of the absence of regulations that have criminal sanctions that regulate his actions, then actually against the perpetrators can not be punished

In terms of determining the limits as a guideline for corporate criminal law enforcement, in accordance with criminal law enforcement system, according to the researcher's point of view, law enforcement officers can rely on general criminal law 
construction by using several general criminal sections in the Criminal Code, including Article 372 KUHP embezzlement), Article 378 of the Penal Code (KUHP), Article 263 of the Penal Code and Article 266 of the Criminal Code (including false information in authentic deeds) to resolve many criminal cases involving corporations. As mentioned above in the text of this dissertation, in this case, the limits of the benchmark are general criminal law instruments as lex generalis.

Meanwhile, remembering on the basis of individual subjects, suffering to prove the errors of corporations, the law enforcement authorities often make the chief of corporate officer (President Director) a representative of the corporation that is responsible for corporate crime. Only then, it can it entrap vice directors, Branch Heads, Division Heads, Supervisors, ordinary employees, and any corporate officer are supervised the President Director. Thus it appears, that seen from a subjective point, involved various person in terms of criminal or corrosion criminal.

Therefore, it can be asserted that the limits of the benchmark must refer to the legal construction of the articles of criminal law of participation as provided in Article 55 and Article 56 of the Criminal Code.

\section{Conclusions}

Based on the results of the description and discussion in the chapters in advance, especially the description in chapter IV, it can be drawn some conclusions.

The political dimension of criminal law on the legal standing of a corporate legal entity as a legal subject in a criminal offense may be general and special. General character related to generalist legal matter. general criminal law which is the content of the Criminal Code (KUHP) which is currently still in the draft of Law No. 1 of 1946.

The general dimensions of criminal politics of corporations formally include choice of forms, types and ways. The dimension of form is to affirm that the development of the penal law against the corporation, selected by written law, is in accordance with the nature and characteristics of the criminal law itself. The legal type of legislation focuses on the choice of the level of legislation, which is by means of the will of revision of the Criminal Code whose planning and concept has been carried out since 1963, and to date it is still listed in the list of national legislation programs. Materially, the general political dimension of corporate criminal law includes the choice of the choice of a continental European legal system, the choice of the punishment model, and the determination of the pattern and types of applicable criminal sanctions. 
Meanwhile, the special political dimension of the penal law against corporations, beyond the substance of the Criminal Code, reflects more about the choice of specific legal objectives (lex specialists) and the choice of criminal law formulation in certain fields (eg, corruption, immigration and the environment life). The political dimension of criminal law in the context of an application-oriented specialist theories of legal entities, especially organ theory and theory of legal reality. Thus, there is no political doubt in the criminal law to determine and confirm that the corporation may commit criminal acts (as a criminal offender) and is therefore construed as a subject of criminal law in the enforcement of criminal law in Indonesia, or in a criminal justice system ). In addition, the special political dimension of corporate criminal law has accommodated the concept of criminal liability, the model of punishment, and the system of sanctions for corporations.

1. The practice or law enforcement process of the corporation as the legal subject of a criminal offense has not proceeded as it should in accordance with the principles of fast, clear, cheap law enforcement. There are things that led to the slow pace of law enforcement practices against corporations as perpetrators of criminal acts. The Criminal Law perspective on corporations covers aspects of civil, administrative, and criminal law, which can not be separated from one another. Therefore, in the enforcement of criminal law against the subject of corporate law is characterized by problems related to these legal aspects. The administrative law aspect is a factor in the middle, in the sense of a shift from the field of civil law to the field of criminal law in the context of the subject of corporation law, mediated by administrative law.

2. As it is known, the problems that arise are the limits of corporate error and accountability related to a criminal act, basically in the field of economic crime. Related to this, on the law enforcement level there is a sense of unease with the tendency to free the perpetrators of the violation under the pretext of not knowing any law prohibiting the actions taken. When a corporation has been designated as a suspect of a criminal offense, there are difficulties. The financial condition of a corporation in the context of criminal proceedings can not be expressed openly because it involves the internal side of the corporation. Against a corporation as a legal entity to disclose information disclosure of a bank account of a party involved in a crime, a suspect status is required.

3. Technically, the law also has problems that are not easily understood, such as the 
difficulty of formulating the identity of the suspect in the Minutes of Investigation (BAP) by the investigator and formulating the identity of the defendant in the indictment by the public prosecutor. It is stated so, because explicitly-normative Article 143 paragraph (2) letter a of the Criminal Procedure Code, determines the formal conditions containing the full name, place of birth, age or date of birth, sex, nationality, residence, religion and occupation of the suspect. For corporations there is no provision that can be referred to analogously. Such circumstances will lead to the cessation of criminal law enforcement with corporations, since the weakness of formulating identities in the indictment may be overturned by a judge. Likewise, in the subsequent criminal proceedings, the corporation can not directly give testimony before the court without explanation from the management. It will be more complex if the corporate officer is also a party categorized as a suspect.

So from the problem problematic as the authors describe above get the results of research and concluded in two cases namely, First: the political dimension of criminal law against the corporation there is a general nature, namely the criminal law politics found in the Criminal Code which is generally oriented to the development of law by placing corporation as a perpetrator of a crime then it is necessary to codify the Law of the Corporation. Secondly: criminal law politics is also of a special nature, that is found scattered in the 16 Laws examined in the context of the concept of criminal responsibility and the application of criminal penalties and models of criminal sanctions that can be imposed on the perpetrators of corporate crime. it is necessary to immediately formulate a single concept of corporate criminal law subject that has been spread in several laws.

\section{Recommendation}

1. In the political perspective of Indonesian law, both the politics of law in general, and especially the politics of criminal law, need to be increased again the commitment of all parties to the alignment to the development of law. The legal political formulation must be explicit and intact and firm, contained in similar core documents MPR Decree. Although the State Policy Guidelines $(\mathrm{GHBN})$ are no longer recognized in the structure of the Indonesian national legal system, it is necessary to document the place where national political law is poured into high-ranking legal documents. Nowadays the most possible and its existence is recognized again based on Law Number 12 Year 2011 is 
MPR Decree. If it can be agreed, the amendment to Law Number 17 Year 2007 on the National Long Term Development Plan will be made, by making changes to the legal political formula (legal policy) independently. The concept of political politics in the RPJPN, more likely to be placed in the paradigm of legal relations with politics more political determinant. This is apparent because the law is still regarded as a field whose position is not higher than politics, even the law is only placed as part and parallel to the field of bureaucracy. Especially, the politics of criminal law against corporations in the broader sense (lex generalis) as set forth in the draft of the Criminal Code, then there should be further discussion between various parties, especially between the government premises of the House, so that criminal law politics against corporations in the Criminal Code can be immediately materialized. In the case of a special corporate criminal law politics (lex specialist), it is necessary to formulate a single concept of corporate criminal law subject that has been spread out in several laws.

2. To be more assertive in practice, it is necessary to provide briefing to all law enforcement officers about the ins and outs of general corporate law, and especially on corporate crime. In fulfilling the technical requirements of the law in handling cases, it is necessary to issue a separate legislation regulating further the identity of the perpetrators of criminal acts which must be included either in the Official Report of Inspection (BAP) by the police, as well as the Indictment by the Public Prosecutor. Therefore, it is necessary to conduct activities of short educational nature, training, or technical courses of criminal

procedure law. Therefore, the development of the political concept of criminal law at the level of law enforcement related to the aspects of criminal, civil and state administration law, it is necessary to conduct a research that functions and recommends a clear separation between the three aspects of the law.

\section{Reference}

1945, N. U. (1945). Naskah UUD.

Adi setyadi dan Rena Yulia. (2010). Hukum Pidana Ekonomi. (G. Ilmu, Ed.) Yogyakarta, Indonesia: Graha Ilmu.

Arifin. (2005). Peran Akuntan dalam menegakan prinsip GCG pada perusahaan d indonesia. Universitas Diponegoro, (p. 8). Semarang. asic.gov.au. (2016, February 16). asshidiqie, J. (2008). Pokok Hukum Tata negara Indonesia Pasca 
Reformasi (Vol. 2). Jakarta: PT. Bhuana Ilmu Populer.

Attamimi, M. F. (2005). Ilmu hukum dan perundang-undangan (Vol. 1). Jakarta, Indonesia: UI.

Bakhri, S. (2009). Hukum pembuktian dalam praktik peradilan pidana . Yogyakarta: Total Media.

Black law Dictionary. (n.d.).

BUMN.go.id. (2016, February 9). Retrieved from www.bumn.go.id

Definition of alter ego. (2016, February 16). Retrieved from Uslegal.com.

KUHP 389.

KUHP 398.

KUHP 399.

KUHP 789.

M, T. (n.d.). Akuntansi Forensik dan Audit Investigatif. In Theodorus. Jakarta: Universitas Indonesua.

Naskah akademik ruu hukum acara pidana. (2008). Retrieved from wordpress.com.

NKRI, N. U. (1945). Naskah UUD NKRI.

Priyatno, M. d. (2010). Pertanggung jawaban pidana korporasi. Jakarta: Fajar pratama offset.

Quinney. (n.d.). Persekongkolan jahat Perusahaan.

Reksodiputro, M. (1993). Tindak pidana korporasi dan pertanggungjawabannya perubahan wajah pelaku kejahatan di Indonesia. Dies natalis kepolisian ke 47. Jakarta.

Soekanto, S. (1986). Pengantar Penelitian

Hukum. Jakarta: Universitas Indonesia.

Theodorus. (2007). Akuntasi Forensik dan Audit Investigatif. Jakarta, Indonesia: Universitas Indonesia.
(1993). Tindak Pidana Korporasi dan Pertanggungjawabanya perubahan wajah pelaku kejahatan di Indonesia. Jakarta.

Undang Undang no 3 (Transfer dana dalam pasal 87 menentukan lain bahwa jika tindak pidana sebagaimana dimaksud dalam pasal 80 sampai dengan 85 dilakukan oleh korporasi pertanggung jawaban pidana dikenakan terhadap korporasi dan pengurusnya 2011).

Undang Undang No 40 tengang perseroan terbatas. (2007).

Undang undang no 6 tahun 2011.

Undang Undang tentang transfer dana, 3 (2011).

Wiyono. (n.d.). Pembahasan Undang Undang Pemberantasan Tindak Pidana Korupsi. Jakarta: Sinar Grafika.

Yeager, M. B. (1980). Corporate Crime. New York: The free press. 